Student Success

ISSN: 2205-0795

Volume 9, Issue 3, pp. 79-86

J uly 2018

\title{
Students guiding students: Integrating student peer review into a large first year science subject. A Practice Report
}

\author{
Renee Dowse, Jacqueline Melvold and Kristine McGrath \\ University of Technology Sydney, Australia
}

\section{Abstract*}

Learning how to give and receive peer review is a skill that science students need support in developing. We included student peer review in an assessment for a large first year science subject. Class time was dedicated to introducing and developing peer review skills and increasing engagement among students and between students and teachers. Students worked in pairs, small groups, and facilitated group discussions and were encouraged to learn from each other. The student peer review exercise provided students with the opportunity to reflect on and improve their work prior to submission. Survey results showed $78 \%$ of students agreed that peer review developed their ability to give constructive feedback. Training and resources provision for the teaching staff was crucial to the integration of peer review activities. Supported teaching staff were able to engage with and support the students, and the students valued this engagement and guidance.

*This report was first presented at the 2018 STARS Conference in Auckland, New Zealand in July 2018 as an 'Emerging Initiative' and was selected by the Conference Committee and Journal editorial team as one of the toprated papers in this category. The authors have kindly given their permission to have this paper published as a Practice Report in this special issue of the Journal and it has undergone a further review by the editors to confirm it aligns with the Journal's standards.

\section{Please cite this article as:}

Dowse, R., Melvold, J., \& McGrath, K. (2018). Students guiding students: Integrating student peer review into a large first year science subject. A Practice Report. Student Success, 9(3), 79-86. doi: 10.5204/ssj.v9i3.471

This practice report has been accepted for publication in Student Success. Please see the Editorial Policies under the 'About' section of the Journal website for further information.

Student Success: A journal exploring the experiences of students in tertiary education

(c) (1) This work is licensed under a Creative Commons Attribution 4.0 International Licence. As an open access journal, articles are free to use, with proper attribution, in educational and other non-commercial settings. ISSN: 2205-0795 


\section{Introduction}

Cell Biology and Genetics (CBG) is a core first year science subject that runs in the two main teaching sessions, Autumn and Spring, at the University of Technology Sydney (UTS). Up to 1,000 students enrol into CBG each year from diverse entrance pathways and backgrounds. One lecturer leads CBG and approximately 45 casual academics (herein called Teaching Associates, or TAs) teach the practical and workshop components of the subject. In large cohorts, students may feel disengaged from teaching staff and from each other. To overcome this, we used the transition pedagogies (Kift, 2009), transition and engagement, to redesign a CBG assessment task.

Peer review occurs regularly in the workplace and is central in science. Learning how to give and receive peer review is a critical skill (Nilson, 2003 ) required in science students, and one that they need support in developing (Pearce, Mulder \& Baik, 2009). Despite this, student peer review is rarely included in first year science curricula. Students are reluctant to fully engage in student peer review because of emotion, being unaware of professional standards and expectations, and laziness in critiquing work and/or writing thoughtful feedback (Nilson, 2003). At UTS, this First Year Experience Project introduces first year science students to peer review and the peer review process, through activities designed to ameliorate these issues

The project was funded by a university-wide First Year Experience grant scheme (Egea, Griffiths \& McKenzie, 2014) that supports the embedding of transition pedagogies into the first year curriculum with the aim of increasing student retention and success. The changes implemented through this project were designed to complement and build on reading practices, online modules and workshops (Davila and Griffiths, 2016) that are delivered in a concurrently run first year core science subject, 'Principles of Scientific Practice' (PSP). However, all project activities were scaffolded and guided to support pathway students and the few students for whom PSP is not a core subject (for example, Advanced Science students). This project supported student transition into a first year science subject by guiding the TAs to actively engage with students, and the students with their peers, the work, and with an introductory level of professional skills.

\section{Using Transition Pedagogies to design a student peer review task for first year students}

Action research "seeks to bring together action and reflection, theory and practice, in participation with others, in the pursuit of practical solutions to issues of pressing concern ..." (Reason \& Bradbury, 2001, p.1). We used an Action Research approach (McNiff, 2001); reflecting on the current assessment task and the learning experience around the task, and observations on concurrently delivered first year subjects. This section describes the observations and changes we enacted as a project team.

\section{Background information: The original assessment task}

The original CBG poster assessment required students to create a scientific conference style poster and present it in class. Students chose a topic of interest from selected scientific journals, researched the literature, identified an article to critically analyse, and prepared a poster presenting that analysis.

Two one-hour workshops supported this assessment task. In the first workshop students were introduced to scientific posters, the components of a research publication, and how to search for peer reviewed literature. They were also provided with online resources and 
taught some presentation skills. In the second workshop, presentation skills were re-iterated, and students submitted a synopsis of their chosen article.

Reflecting on this form of the assessment revealed some areas for improvement which were addressed in the second iteration discussed further below. First, students were not given a marking rubric, and no formative feedback was provided to them prior to their poster submission. Further, both workshops took place in tutorial rooms with no student access to university computers. Finally, the workshop structure was inconsistent between the different classes and TAs, and the TAs needed fuller support in relation to the delivery of the workshops.
Using transition and engagement pedagogies to design a peer review and scientific poster assessment task

The original student workshops were restructured to scaffold the new learning experiences. The new assessment task and workshops were designed to provide all students with a uniform level of understanding of the task, formative feedback through the introduction of peer review, and thoughtful engagement in the task through interactive software and self-reflection (Figure 1). We designed guided activities whereby the students could gain a deep understanding of the assessment task.

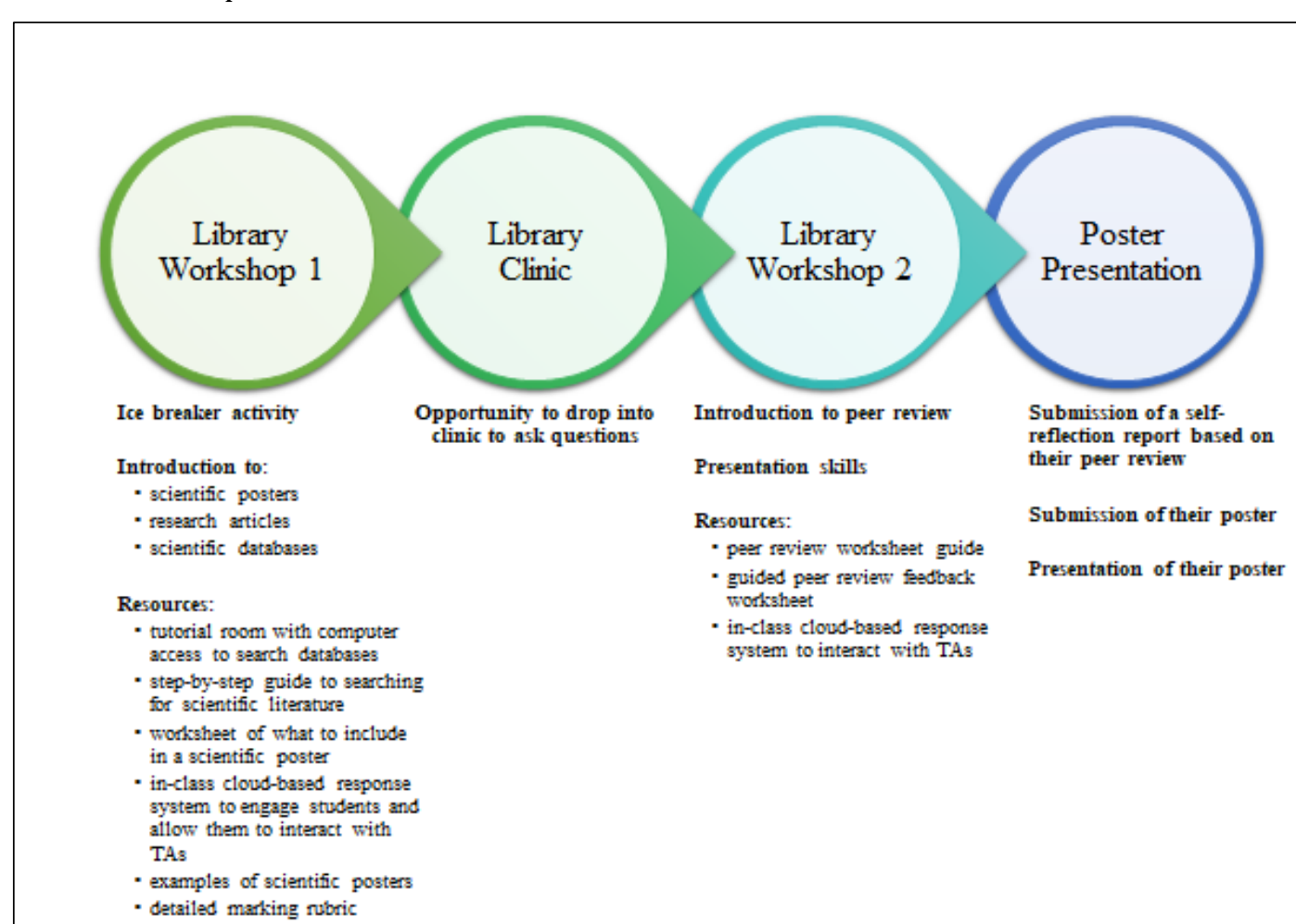

Figure 1. A schema of the peer review and scientific poster assessment task activities as undertaken by the students 
Online resources on scientific articles and how to create a scientific poster were collated and made available to the students and class time was dedicated to discussing the activities. The expectations of the assessment were made explicit to the students through the provision of a detailed marking rubric, which included allocation of marks for peer review and selfreflection.

To create and grow a sense of belonging within the large cohort, students shared ideas in small groups and then in facilitated class discussions, interacting and engaging with their peers and TAs. Each workshop was extended to two hours and conducted in the University library computer rooms. Although the workshops were not compulsory we expected very high attendance, firstly because Workshop 1 was in the first week of the session, and secondly because students were required to submit a reflection paragraph based on Workshop 2 activities.

\section{Library Workshop 1}

We introduced an icebreaker as the first activity in Library Workshop 1 . The TAs then explained the assessment task and the components of scientific research articles, using the same presentation slides across all classes and an online engagement tool, Socrative (https://www.socrative.com/), to better understand the levels of student awareness about the assessment task requirements. Guided by the TAs, students navigated the literature using the library databases to find the article they would present based on their chosen poster topic. This activity was designed in collaboration with UTS library staff, who developed a step-by-step guide to searching scientific literature in the UTS library website. Guided by a worksheet, students identified the important information from the article to be used to create their poster.

\section{Library Workshop 2}

An aim of the redesigned assessment task was to introduce the students to the professional skill of providing constructive criticism. However, most of the first year students lacked the disciplinary knowledge, in this case of peer review, to respond to questions at a professional standard (Nilson, 2003). To prepare the students for peer review prior to undertaking the exercise, TAs facilitated a class discussion on constructive, actionable feedback using previously submitted posters (Pearce et al., 2009) and examples of actionable and constructive feedback. In small groups, students discussed their critique of the example posters and answered questions using the same online engagement tool that they used in Workshop 1. This was followed by a class discussion, sharing ideas on how each poster could be improved and how to translate these ideas into constructive feedback (or, peer review). In preparation for self-reflection, the students learnt about the 5R Model of reflection (Bain, Ballantyne, Lester, \& Mills, 2002) with guided examples of how each section of the model could be used for their reflection.

Students brought a copy of their chosen article and a draft copy of the poster they created to class. The draft poster was displayed anonymously. In pairs, students circulated around the room, and using a peer review feedback worksheet they reviewed their peers' posters. The worksheet contained objective questions that when answered provided formative feedback aiming to help clarify the writing and improve the work (Pearce et al., 2009). The TAs guided this process and supported students in the formation of their critiques to ensure they were constructive and actionable.

Each student received at least three peer reviews of their draft poster. Based on the reviews, they wrote a one-paragraph reflection describing how they could use the feedback to 
improve their work. The TAs were advised to acknowledge students who voiced doubts about the accuracy of their given feedback, and to encourage these students to research further (Gielen, Peeters, Dochy, Onghena \& Struyven, 2010 ) to see if they could validate their own thoughts with evidence.

\section{Supporting Teaching Associates supports students}

Staff commitment is vital to the success of first year support strategies (Potter \& Bye, 2014). In this project, the briefing of TAs on why we included peer review, how to peer review and the benefits of peer review was critical to the success of implementing student peer review into the curriculum. The UTS Faculty of Science financially supports pre- and post-session meetings between teaching staff within a subject. We utilised this funding to pay the TAs to attend a workshop prior to the delivery of the task. During this workshop TAs familiarised themselves with the interactive software and new content (Figure 2). The workshop was also important to ensure consistency across the 45 TAs in their classes and to advise the TAs on what was expected of them, and what was expected of the students.

We created resources to support the TAs (Figure 2), including a 'Background Information' and 'Teaching Tips for Teaching Associates' 'cheat sheet' for them to take away from the workshop. This sheet suggested ways in which TAs could engage with students, encourage collaboration between students, and

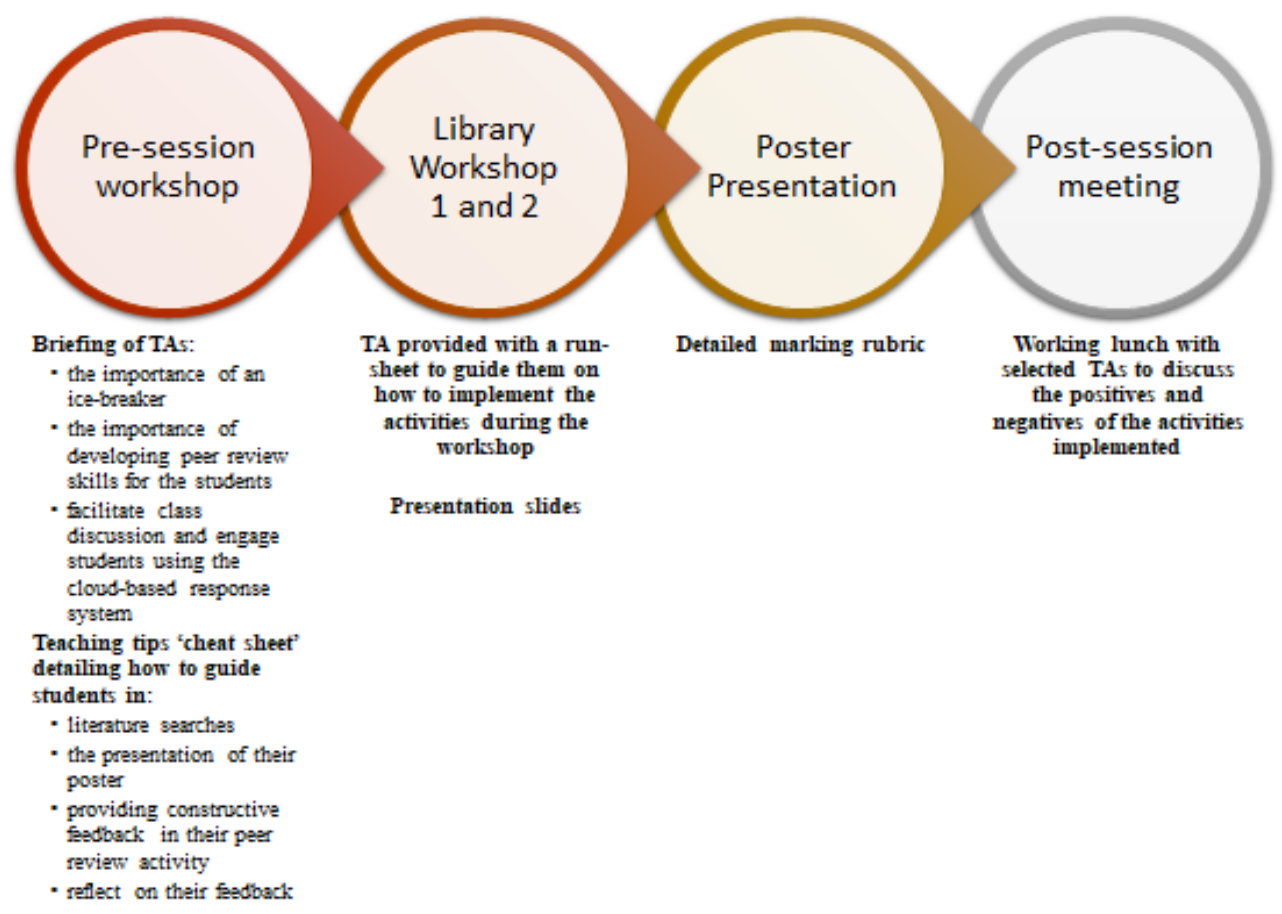

Figure 2. A schema of the resources developed to support Teaching Associates 
Students guiding students: Integrating student peer review into a large first year science subject. A Practice Report

\section{Table 1}

\section{Student evaluation survey results of student peer review workshops}

\begin{tabular}{|l|c|c|c|c|c|}
\hline \multicolumn{7}{|c|}{ Question } & $\begin{array}{c}\text { Strongly } \\
\text { agree }\end{array}$ & Agree & Neutral & Disagree & $\begin{array}{c}\text { Strongly } \\
\text { disagree }\end{array}$ \\
\hline $\begin{array}{l}\text { The Teaching Associates presented the } \\
\text { material in a manner that was engaging and } \\
\text { easy to understand }\end{array}$ & 33.2 & 46.5 & 17.7 & 2.0 & 0.6 \\
\hline $\begin{array}{l}\text { The Teaching Associates created a learning } \\
\text { environment which encouraged interaction } \\
\text { amongst my peers }\end{array}$ & 29.8 & 46.1 & 19.2 & 4.0 & 0.9 \\
\hline $\begin{array}{l}\text { The workshop helped me understand the } \\
\text { importance of peer review and reflection in } \\
\text { science }\end{array}$ & 27.8 & 51.9 & 16.0 & 3.7 & 0.6 \\
\hline $\begin{array}{l}\text { The peer feedback activity developed my } \\
\text { ability to give constructive feedback }\end{array}$ & 23.8 & 54.2 & 17.0 & 4.1 & 0.9 \\
\hline $\begin{array}{l}\text { The reflective task facilitated my } \\
\text { understanding of what I learnt in this } \\
\text { assessment task }\end{array}$ & 17.6 & 43.9 & 27.5 & 10.4 & 0.6 \\
\hline
\end{tabular}

help the students thoughtfully and deeply engage with the class activities, their work and the work of their peers. For consistency across the workshops, TAs were given a run-sheet and presentation slides for each workshop. At the end of the Autumn session, project developers and selected TAs who had previously taught CBG participated in a working lunch to share insights and input into the content and running of the workshops.

\section{Project outcomes and evaluation}

The Student Feedback Survey showed 'The Overall Satisfaction with Quality of Subject' result improved from 3.34 out of 5 (prior to our project) to 3.92 out of 5 (post-project). Because we had largely changed the marking rubric for the assessment task there was no validity in comparing current student assessment marks to those attained prior to the implementation of our project. During the Autumn teaching session and on conclusion of the poster presentation session, students (approximately 600) and TAs were surveyed anonymously to assess the success of the redesigned assessment task, library workshops and TAs workshop.

Student survey results $(n=409)$ show that approximately $80 \%$ agreed that they engaged with the TAs and the work, and approximately 76\% agreed that the learning environment encouraged engagement with their peers (Table 1). Students commented on engagement with the TAs and their work and how the library workshops assisted their transition to UTS:

To ask any questions and to check whether or not I was on the right track for e.g. the posters. The library workshops provided students with an idea on how to use the library resources such as the databases on UTS library on where to find a good article/sources. 
Table 2

Teaching Associate evaluation survey results of student peer review workshops

\begin{tabular}{|l|l|l|l|l|l|}
\hline \multicolumn{7}{|c|}{ Response (\%, n=17) } \\
\hline Question & $\begin{array}{l}\text { Strongly } \\
\text { agree }\end{array}$ & Agree & Neutral & Disagree & $\begin{array}{l}\text { Strongly } \\
\text { disagree }\end{array}$ \\
\hline $\begin{array}{l}\text { There was adequate support to assist in the } \\
\text { delivery of library workshop 1 }\end{array}$ & 68.8 & 31.2 & 0.0 & 0.0 & 0.0 \\
\hline $\begin{array}{l}\text { There was adequate support to assist in the } \\
\text { delivery of library workshop 2 }\end{array}$ & 56.3 & 43.7 & 0.0 & 0.0 & 0.0 \\
\hline $\begin{array}{l}\text { Students were engaged in the peer feedback } \\
\text { activity }\end{array}$ & 37.5 & 37.5 & 18.8 & 6.2 & 0.0 \\
\hline
\end{tabular}

Students agreed that peer review was an effective formative feedback tool:

The most useful part of the library workshops was the peer review session which gave us an opportunity to reflect and receive a new perspective on the assessment allowing me to look back on my work with a new view and rectify any issues accordingly." and "I found the peer review workshop to be the most useful as it aided me a lot in refining my poster.

From the TA survey responses $(n=17), 75 \%$ agreed that the students were engaged in the peer review activity (Table 2). The TAs commented on how this project improved student learning and outcomes, and on the students' engagement with the task:

The library workshops have definitely improved from previous years. Students seemed to have a better grasp of the assessment task. Workshop 1: They were able to search for articles on the day, and we were able to help them with that. In my class, this resulted in students picking research articles and not review papers.
Workshop 2: Everyone had their draft posters ready and were able to get constructive feedback from the class"

Overall, the library workshops were such a huge improvement. I could tell by the quality of the presentations - the students were significantly more engaged with their work, and a lot of the common errors were ruled out during the second workshop (such as students choosing reviews, or articles from the wrong year, or making cluttered posters that were impossible to read.

Supported engagement is important for peer learning programs (Adam, Skalicky \& Brown, 2011), and the importance of such support is transferable to the classroom. In our project, all surveyed TAs felt supported to deliver the library workshops (Table 2), and said that student-TA engagement improved student-tostudent engagement and student-to-task engagement:

I do believe it improves student engagement and understanding of the task 
by actively allowing tutors to participate in the learning process.

The working lunch with selected TAs resulted in improvements to the workshop content and the running of the face-to-face classes, highlighting the valuable contribution that teaching associates can make to teaching and assessment processes (Bentley-Williams, 2017).

\section{Conclusion}

Using transition and engagement pedagogies to design student peer review activities resulted in a formative learning process, and facilitated engagement between students, their teaching staff, with the work, and the work of their peers. Evaluation survey results show that students engaged with the work and their peers, and that TAs felt supported to deliver the peer review activities. We recommend that supporting staff through training and resource development, and dedicated, supported class time in which students can develop their skills and refine their work are crucial for engaging a large cohort with peer review.

\section{Acknow ledgement}

This project was supported by a UTS Widening Participation Strategy First Year Experience grant, funded through the Australian Government Higher Education Participation and Partnership Program (HEPPP). Meijun Huang developed the UTS library resources. Comments from Yvonne Davila, Elaine Huber and Professor Rachael Field improved this manuscript.

\section{References}

Adam, A., Skalicky, J., \& Brown, N. (2011). Planning sustainable peer learning programs: An application and reflection. International Journal of the First Year in Higher Education, 2(2), 9-22. https://doi.org/10.5204/intjfyhe.v2i2.81

Bain, J., Ballantyne, R., Lester, N., \& Mills, C. (2002). Reflecting on Practice: Student Teachers'

Perspectives. Post Pressed, Flaxton, Queensland.
Bentley-Williams, R. (2017). Engaging university casual tutors in collaborative reflection for improving student learning outcomes. Reflective Practice, 18(4), 540-553.

https://doi.org/10.1080/14623943.2017.1323732

Davila, Y.C., \& Griffiths, N. (2016, June/July). Supporting student transition: embedding reading practices into the first year Science curriculum. Paper presented at the 2016 STARS 2016 Conference, Perth, Australia. Retrieved from http://unistars.org/papers/STARS2016/12C.pdf

Egea, K., Griffiths, N., \& McKenzie, J. (2014). An evolving approach to developing academics' understanding of transition for first year students. A Practice Report. The

International Journal of the First Year in Higher Education, 5(2), 103-109. https://doi.org/10.5204/intjfyhe.v5i2.235

Gielen, S., Peeters, E., Dochy, F., Onghena, P., \& Struyven, K. (2010). Improving the effectiveness of peer feedback for learning. Learning and Instruction, 20(4), 304315.

https://doi.org/10.1016/j.learninstruc.2009.08.007

Kift, S. (2009). Articulating a transition pedagogy to scaffold and to enhance the first year student learning experience in Australian higher education: Final report for ALTC senior fellowship program: Australian Learning and Teaching Council Sydney, Australia. Retrieved from http://transitionpedagogy.com/wpcontent/uploads/2014/05/Kift-Sally-ALTC-SeniorFellowship-Report-Sep-09.pdf

McNiff, J. (2001). Action Research: Principles and practice (2nd ed.). London: Routledge.

Nilson, L. (2003). Improving student peer feedback. College Teaching, 51(1), 34-38. https://doi.org/10.1080/87567550309596408

Pearce, J., Mulder, R., \& Baik, C. (2009). Involving students in peer review. Case studies and practical strategies for university teaching. Retrieved from the Centre for the Study of Higher Education website https://melbournecshe.unimelb.edu.au/data/assets/pdf file/0011/1 761518/Student Peer Review.pdf

Potter, A., \& Bye, L. (2014). "It might have worked for you but ..." Evaluating the efficacy of a first year support strategy in multiple units and disciplines. International Journal of the First Year in Higher Education, 5(2), 57-68. https://doi.org/10.5204/intjfyhe.v5i2.232

Reason, P. \& Bradbury, H. (Eds.). (2001). Handbook of action research: Participative inquiry and practice. London: Sage Publications. 